\title{
Middle Palaeolithic find spots with Nubian cores from the Southern Negev and the Arava, Israel
}

\author{
Mae Goder-Goldberger ${ }^{1}$, Hanan Ginat ${ }^{2}$, Gidon Ragolski ${ }^{2}$, Gregory Seri ${ }^{3}$, \\ Itay Abadi $^{1}$ \\ 1 Institute of Archaeology, The Hebrew University of Jerusalem, Mt. Scopus, 91905, Jerusalem, Israel. \\ Email: Goder-Goldberger: mae.goder@mail.huji.ac.il; Abadi: itay.abadi@mail.huji.ac.il \\ 2 Dead Sea and Arava Science center, Tamar regional council, Dead-Sea M.P. 86910, Israel. \\ Email: Ginat: hanan@arava.co.il; Ragolski: gidon@arava.co.il \\ 3 Israel Antiquities Authority, POB 586, Jerusalem, 91004, Israel. Email: gregory@israntique.org.il
}

\begin{abstract}
:
This is a report of results from a cursory survey of several Middle Paleolithic find spots from the Arava, Israel, conducted as part of a broader collaboration between the Dead Sea and Arava Science Center and the Israel Antiquities Authority. A series of find spots were recorded on the eastern flanks of the Zehiha hills and on the northern terraces of Wadi Paran. These finds consist of mostly Middle Paleolithic artifacts including Levallois centripetal, bidirectional and Nubian cores. The presence of Nubian cores within this technological constellation is of interest in light of recent discussions regarding archaeological markers of modern human dispersals out of Africa and feasible routes into Eurasia and Arabia. The Nubian core technology, a specific variant of the Levallois technology is found within a defined and continuous geographic region and is perceived as penecontemporaneous. Sites with a similar technological package are found to the east at Al-Jawf, within the Arabian Peninsula, as well as to the North-West, within the central Negev highlands, at the localities of Har Oded and H2. The distinctive technological characteristics, geographical extent and chronology advocate its use as a possible marker for human dispersals and interactions between Eastern Africa, the Nile Valley, the southern Levant and Arabia.
\end{abstract}

Keywords: Nubian technology; Middle Paleolithic; Southern Levant; surface sites; Out of Africa; dispersals

\section{Introduction}

The Nubian technology is a specific variant of the Levallois technology (GoderGoldberger et al. 2016, Guichard \& Guichard 1965; 1968; Usik et al. 2013; Van Peer 1992) found within Middle Paleolithic techno-complexes at surface sites across the western High Desert in Egypt (Chiotti et al. 2009; Olszewski et al. 2005), the central Negev highlands ISSN: 2055-0472. URL: http://journals.ed.ac.uk/lithicstudies/

This work is licensed under a Creative Commons Attribution 2.5 UK: Scotland License. 
(Goder-Goldberger et al. 2016) and Arabia (Crassard \& Hilbert 2013; Hilbert et al. 2016; 2017; Rose et al. 2011; Usik et al. 2013). Common to these finds is a technological package composed of the Levallois Nubian technology alongside both Levallois centripetal and bidirectional modes of production. Although sparse, all dated assemblages containing Nubian technology are assigned to MIS5 (Mercier et al. 1999; Rose et al. 2011; Schmidt et al. 2015; Van Peer \& Vermeersch 2007; Van Peer et al. 2010). The distinctive technological characteristics, geographical extent and chronology advocate using the Nubian technology as a possible marker for human dispersals and interactions between Eastern Africa the Nile valley the southern Levant and Arabia (Crassard \& Hilbert 2013; Goder-Goldberger et al. 2016; Hilbert et al. 2017; Rose et al. 2011; Usik et al. 2013).

The objective of this paper is to report on two new localities, composed of several find spots, with Middle Paleolithic finds including Nubian cores. The localities; Nahal Paran 9 and Nahal Zihor 6, are situated within the Paran plains in the Arava (Figures 1 and 2). These find spots were discovered during a cursory survey conducted in the Arava region by Dead Sea and Arava Science Center (DSASC) and the Israel Antiquities Authority (IAA). The Arava today is a hyper arid environment cut by dry waterways and covered by desert pavements (Avni et al. 2011; Ginat 1997), although evidence for periods of higher levels of humidity and semi-desert conditions are present (Ginat et al. 2003; Waldmann et al. 2010). The findings from these two localities bridge a gap in the geographical extent between the Negev Highland and central Arabia adding data to the ongoing of recent discussions regarding archaeological markers of modern human dispersals out of Africa and feasible routes into Eurasia and Arabia (Breeze et al. 2016; Goder-Goldberger et al. 2016; Groucutt et al. 2015; Hilbert et al. 2017).

\subsection{Technological background}

The Levallois reduction system is recognized as a technological marker of Middle Paleolithic industries. This technology has been used at sites in varying environmental settings thousands of kilometers apart and across a vast time span (Goren-Inbar \& BelferCohen 1998; Rots \& Van Peer 2006; Shea 2003; 2006; Villa et al. 2005). The Levallois technology, is defined by a basic technological recipe (as defined by Boëda 1988), involving two main methods; preferential for the removal of a single predetermined end product and recurrent for the removal of a series of predetermined flakes from a given flaking surface (Boëda 1988; 1995; Bordes 1961). A Levallois core is defined by a planimetric mode of exploitation, while maintaining a hierarchy between the flaking and shaping surfaces of the core (Bordes 1961). End products are determined by the organization of core geometry and surface topography resulting in three main morphotypes; flakes, points and blades (Van Peer 1992).

Nubian Levallois technology was initially suggested to represent a technological component found within different local lithic industries confined geographically to the Nile Valley and Nubia (Guichard \& Guichard 1965; Marks 1968; Van Peer 1992). The Nubian flaking system is unique and includes identifiable cores, preparation blanks and end products. Nubian cores are defined by four main technological traits (Usik et al. 2013); a steep distal ridge, an opposed striking platform, a triangular or semi-triangular shape, and a prepared main striking platform. (For further discussion see Goder-Goldberger et al. 2016 and Usik et al. 2013).

\subsection{Geographic and climatic background}

The study area is located within the Paran plains, situated between the central Negev highlands in the northwest to the Dead Sea rift in the east (Figure 2). The southern Negev is drained by Nahal Zihor, Nahal Hiyyon and Nahal Paran, all of which flow into the central 
Arava Valley. Geologically, this area consists mainly of marine sedimentary rocks of Cretaceous and Tertiary age. Limestone of Cenomanian-Turonian Judea Group is exposed along the uplifted margins of the southern Arava Valley and in the Zenifim anticline, of which the Zehiha hills are part of (Figure 2). Chalk, chert and marl of the Senonian-Paleocene Mount Scopus Group dominate the structural depression between the Zenifim anticline and the uplifted Arava margin, while Eocene chalk of the Avdat Group is found mainly in the northern part of the area. Extensive areas within the drainage basins of Nahal Paran, Nahal Hiyyon and Nahal Zihor are mantled by fluvial-lacustrine sediments of the Pliocene Arava Formation. These sediments where deposited by a regional fluvial system which drained the southern Negev, eastern Sinai, and part of the eastern margins of the rift, flowing northward to the Dead Sea (Avni 1998; Avni et al. 2001; Ginat 1997; Ginat et al. 2003).

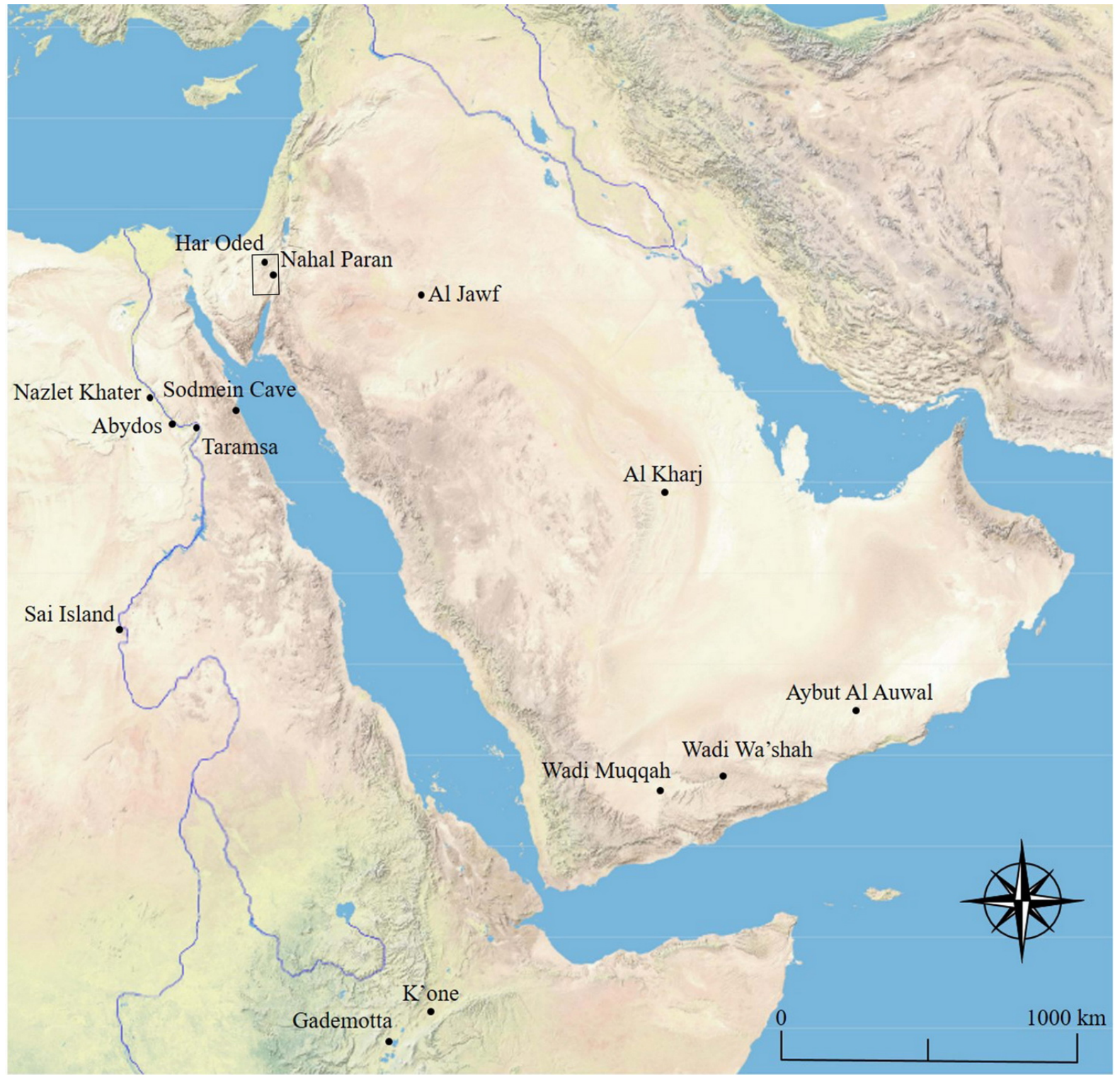

Figure 1. Regional map, noted are Middle Paleolithic sites with Nubian technology, the research area is marked by the black rectangle

The climate in the area is extremely arid. The mean annual precipitation is $50 \mathrm{~mm}$, usually falling in a few rainfall events per year. Past climatic records indicate that during glacial and interglacial periods between MIS 6 and MIS 4 the central Negev was mostly dry (Amit et al. 2006; Vaks et al. 2007), whereas short humid episodes (Negev Humid Periods, 
NHP), possibly resulting from a northern shift of the African Monsson system, occurred during interglacial times (Blome et al. 2012; Kutzbach \& Liu 1997; Larrasoaña et al. 2013; Torfstein et al. 2015; Vaks et al. 2010). The last of the NHP (NHP-1) is dated to 142-109 ka and was synchronous with pluvial periods in the Sahara, the Egyptian Desert and the Arabian Peninsula (Osborne et al. 2008; Osmond \& Dabous 2004; Petit-Maire et al. 2010; Rosenberg et al. 2011; 2012; Yehudai et al. 2017; Vaks et al. 2006; 2007; 2010). Terrestrial corridors between the Negev and Arabia, along which there were sufficient water sources, have been suggested to exist during MIS5 (Breeze et al. 2016).

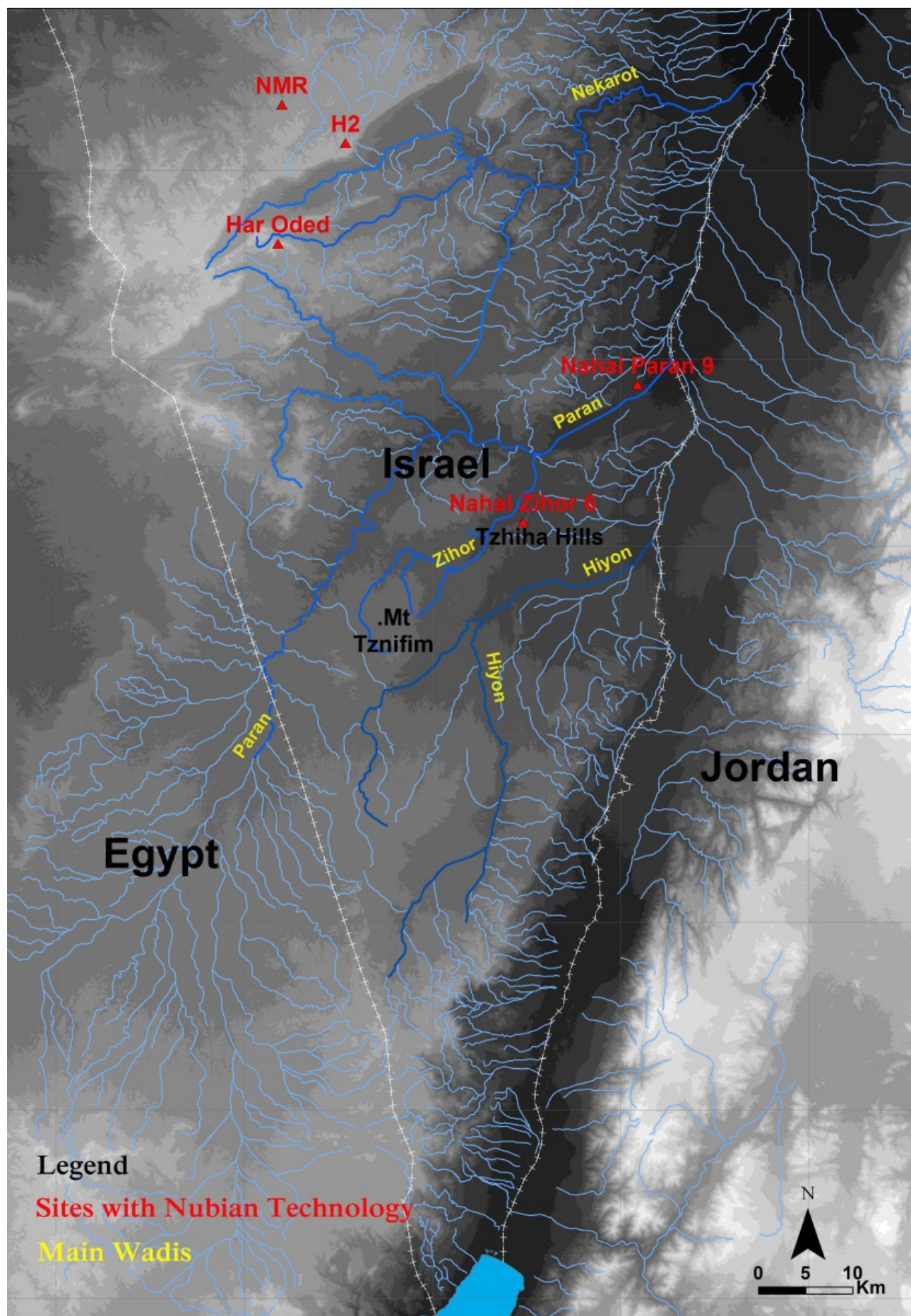

Figure 2. Map of the main wadis and their tributaries in the central Negev and Arava (marked as a rectangle on previous map). In red are Middle Paleolithic surface sites with Nubian technology. 


\section{The localities}

Nahal Zihor 6 (Figure 2) is situated South of Nahal Zihor on the eastern fringe of Zehiha hills, at an elevation of $360 \mathrm{~m}$ above sea level (ASL). The Zehiha hills are the main water divide between the drainage basins of Nahal Zihor and Nahal Hiyyon. Nahal Paran 9 is comprised of several separate finds spots on a desert pavement at an elevation of $115 \mathrm{~m}$ ASL, north of Wadi Paran, the largest drainage basin in the study area.

\subsection{Nahal Zihor 6 (IAA No. 51964/0)}

This find spot covers an area exceeding $200 \mathrm{~m}^{2}$ and is spread across the top of the eastern Zehiha hills (Figure 3).

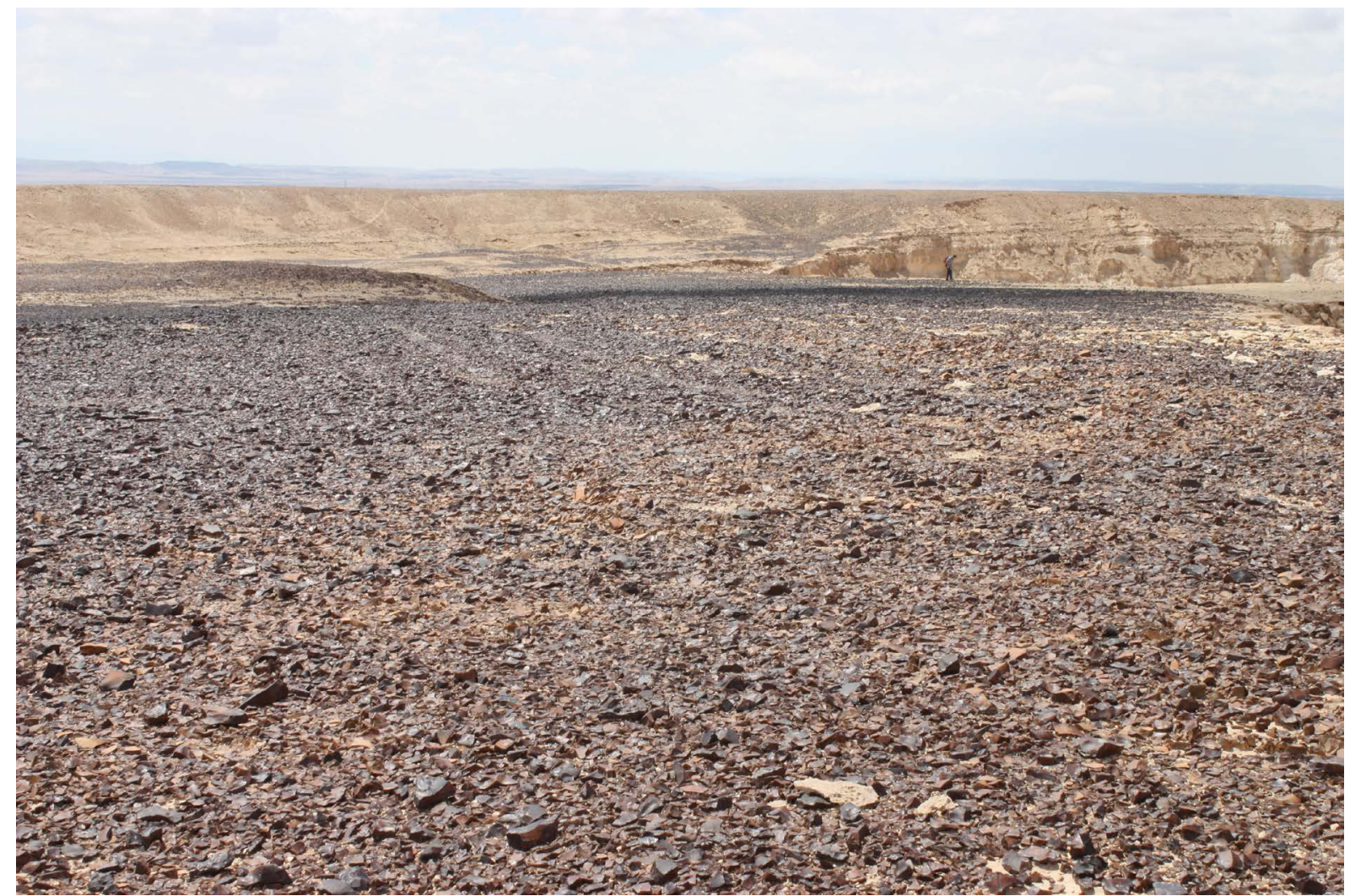

Figure 3. General view of the desert pavements on the top of Zehiha hills.

Within the area surveyed numerous concentrations of Middle Paleolithic artifacts were noted. Field observations indicate that all artifacts in these concentrations were produced by Middle Paleolithic technologies. Nubian cores (Figure 4a,b) were found in association with centripetal and bidirectional Levallois cores. Some of the scatters were composed of both cores and debitage, while others were mostly composed of cores. Of special note is the presence of large thin flint slabs that were used as Levallois cores, mostly for centripetal recurrent flaking (Figure $4 \mathrm{~b}$ and 5). These cores are 30-40 cm in length and only a few $\mathrm{cm}$ thick. While no cortex appears on the flaking surface, the preparation face is covered almost entirely by cortex, with only small preparation flakes removed from the circumference of the face. Only a handful of artifacts were collected for scanning (Figure 5) from this site thus the ratio between Nubian core and other Levallois and non Levallois cores at this find spot is not available. 

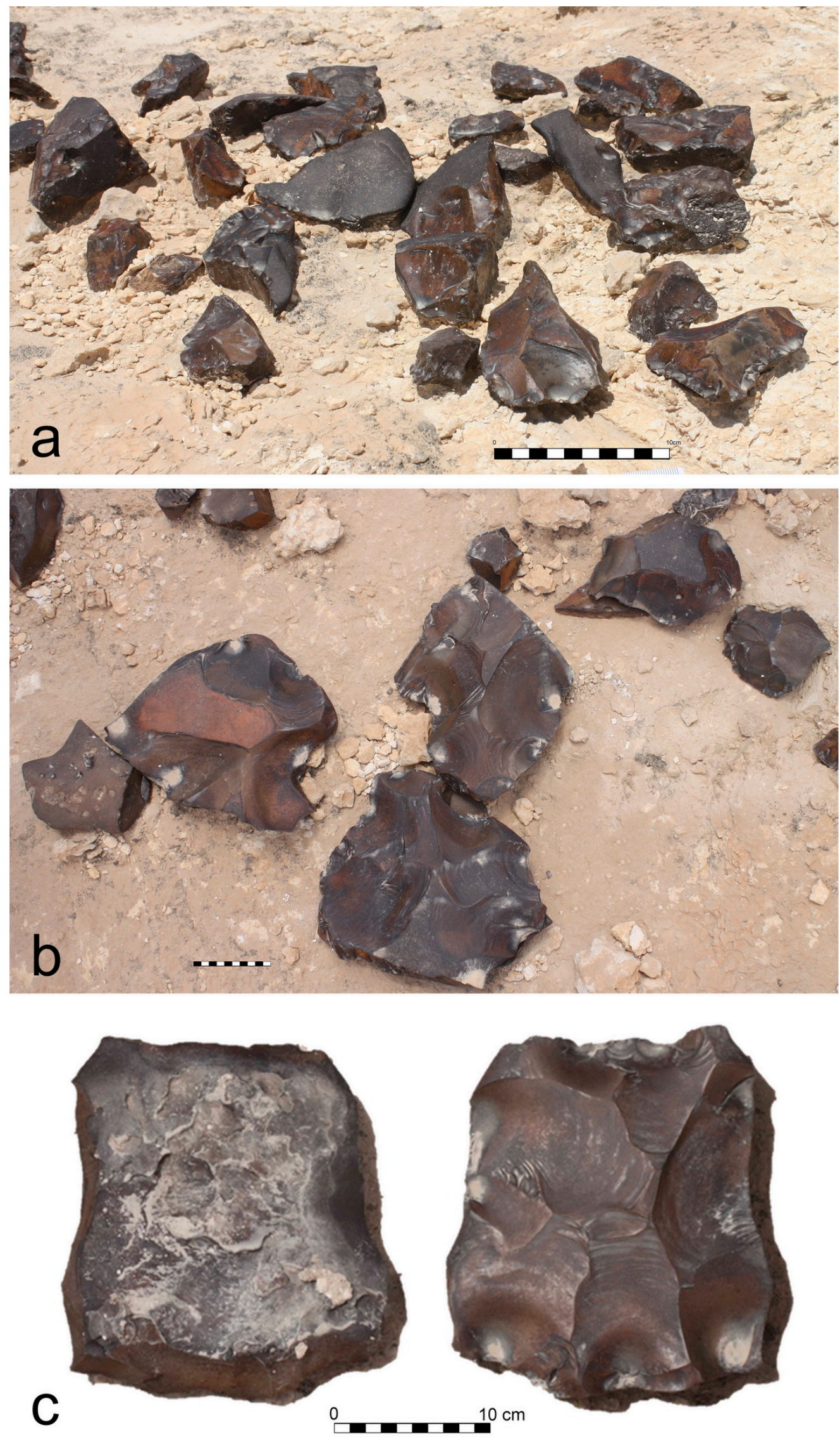

Figure 4. Nahal Zihor 6 a) Close look at one of the artifact concentrations from the Zehiha hills. Notice the Nubian core in the center of photo. b) A second concentration with large Levallois cores on thin flint slabs. c) Large Levallois plaque core. Scale bars are $10 \mathrm{~cm}$ wide, divided into $1 \mathrm{~cm}$ sections. 

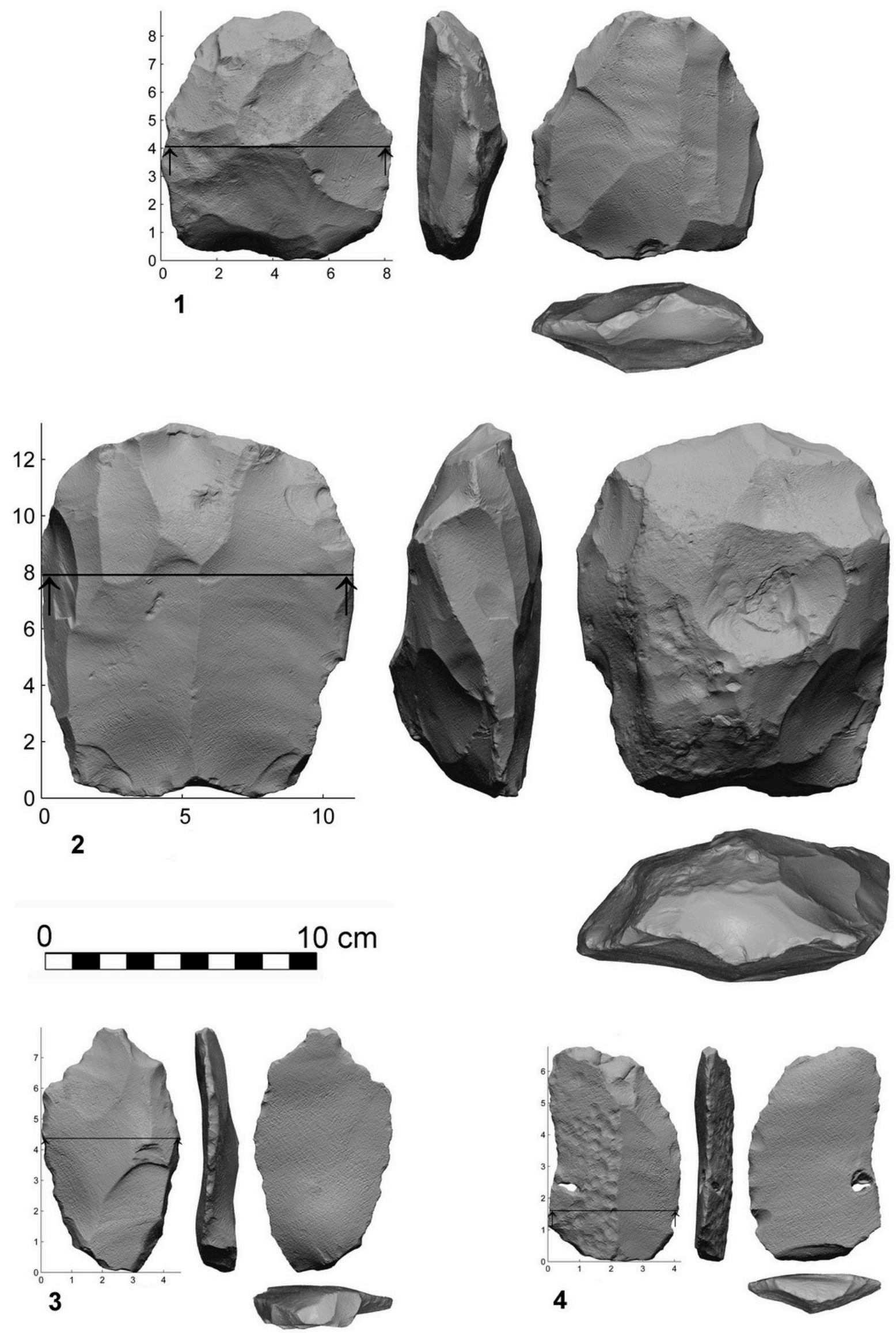

Figure 5. Nahal Zihor 6 - 3D scans of artifacts - 1,2 Levallois cores, 3,4 Large flakes. 


\subsection{Nahal Paran 9 (IAA No. 51965/0)}

On the Northern terraces of wadi Paran there is a desert pavement comprised mostly of Eocene flint nodules (Figure 6a). Amongst the spread of natural flint nodules there is an abundance of anthropogenically modified flints, mostly Middle Paleolithic artifacts (Figure $6 b)$.

\section{a}
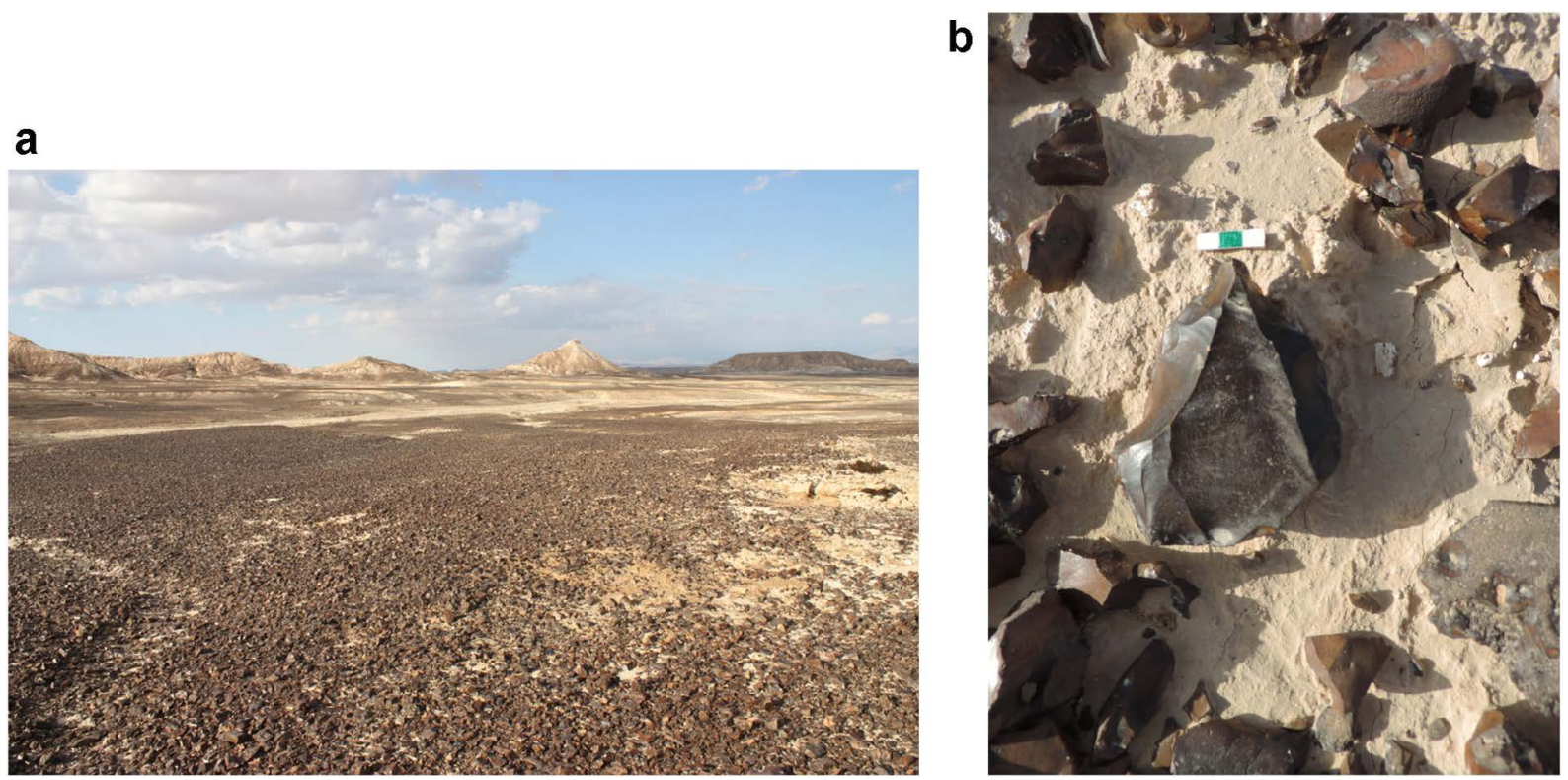

Figure 6 a) View North across the desert pavement adjacent to wadi Paran. b) A Nubian core within the desert pavement. The scale bar is $3 \mathrm{~cm}$ wide divided into $1 \mathrm{~cm}$ sections.

At Nahal Paran 9 three find spots were marked less than $200 \mathrm{~m}$ apart. In the course of the initial survey 11 Levallois cores (Table 1, Figure 7: 2-12 and Figure 8:1-3) and one Levallois point were randomly collected.

Table 1. Dimensions of collected cores from Nahal Paran 9.

\begin{tabular}{|c|c|c|c|c|c|}
\hline Core ID numbers & $\begin{array}{c}\text { Length } \\
(\mathrm{mm})\end{array}$ & $\begin{array}{l}\text { Width } \\
\text { (mm) }\end{array}$ & $\begin{array}{c}\text { Thickness } \\
\text { (mm) }\end{array}$ & $\begin{array}{c}\text { Distal ridge } \\
\text { angle }\end{array}$ & $\begin{array}{c}\text { Length of last } \\
\text { dominant } \\
\text { scar (mm) } \\
\end{array}$ \\
\hline \multicolumn{6}{|c|}{ Centripetal preferential } \\
\hline $346-2$ & 114.8 & 110.6 & 33.8 & & 101.2 \\
\hline $346-5$ & 114.6 & 116.5 & 45.6 & & 77.7 \\
\hline $346-4$ & 113.7 & 103.3 & 28.3 & & 88.1 \\
\hline $346-7$ & 110.1 & 93.3 & 27.7 & & 101.4 \\
\hline \multicolumn{6}{|c|}{ Bidirectional preferential } \\
\hline $346-1$ & 107.1 & 90.3 & 29.7 & & 79.6 \\
\hline $346-6$ & 105.5 & 105.7 & 41.5 & & 72.8 \\
\hline \multicolumn{6}{|l|}{ Nubian Type I } \\
\hline $346-3$ & 133.6 & 103.1 & 26.1 & $80^{\circ}$ & 111.1 \\
\hline 344-1 & 130.1 & 103.4 & 40.7 & $70^{\circ}$ & 92.6 \\
\hline $345-1$ & 111.3 & 89.4 & 45.4 & $80^{\circ}$ & 84.4 \\
\hline \multicolumn{6}{|l|}{ Nubian Type II } \\
\hline $344-2$ & 104.6 & 105.7 & 38.2 & & 94.9 \\
\hline
\end{tabular}



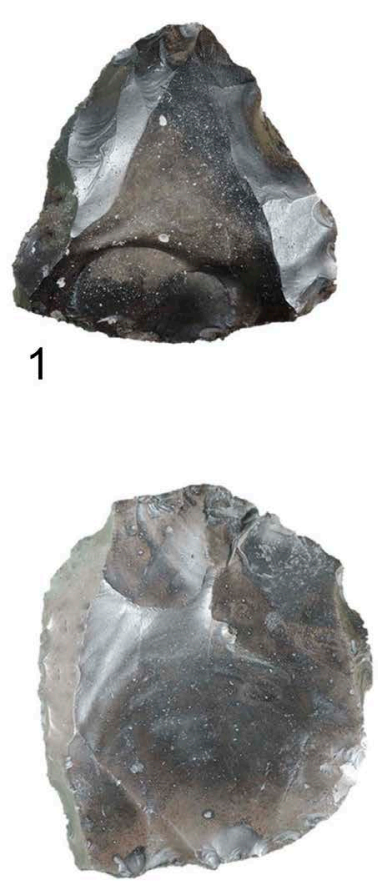

5
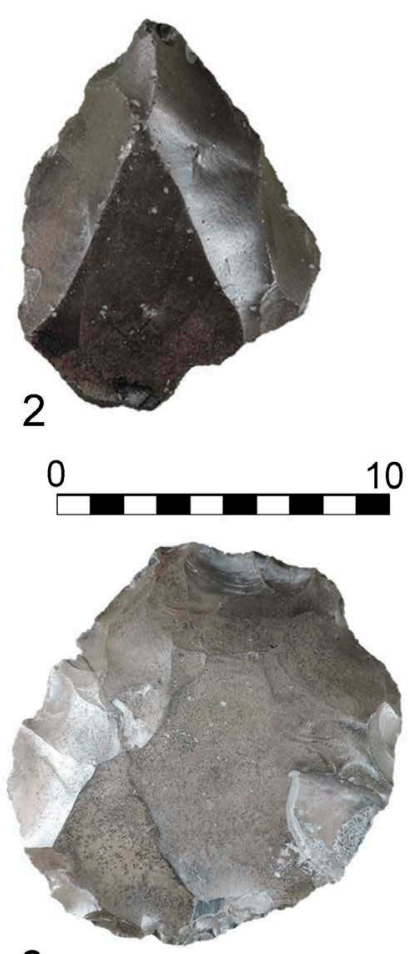

6

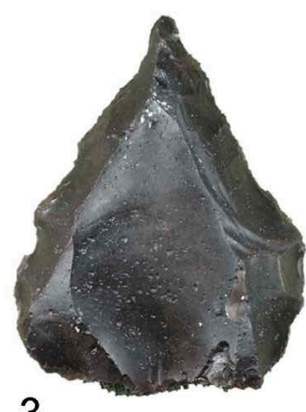

3

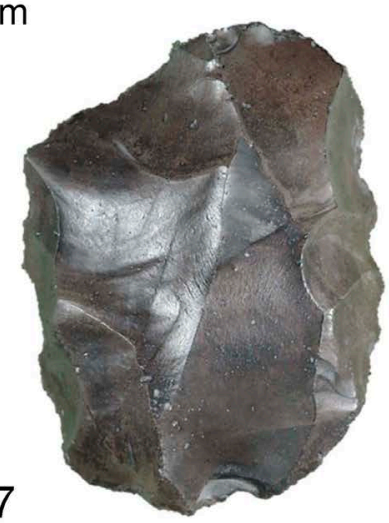

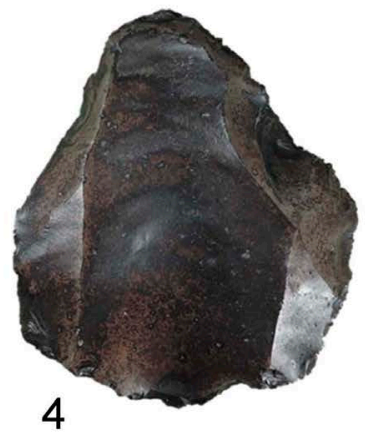

8

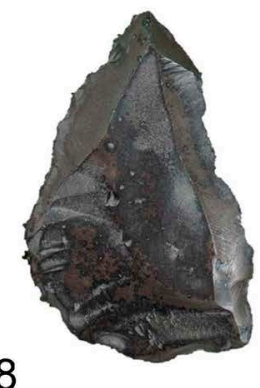

Figure 7. Selected artifacts from Nahal Paran 9: 1, Nubian Type II core (1-344_2), 2-3 Nubian Type I cores (2345_1; 3-344_1), 4-6 Levallois centripetal preferential cores (4-346_7; 5-346_4; 6-346_5), 7 Levallois bidirectional preferential for a point (346_1). 8, Levallois or Nubian point (346_8).

Length was measured along the axis of the last dominant scar on the flaking surface. Width was measured perpendicular to the length at the widest point. The ridge angle for Nubian cores was measured following Usik et al. (2013). Two of the Nubian cores are the largest and all the Nubian cores display semi-steep Angles of the medial distal ridge (Table 1).

To allow an estimation of assemblage densities at Wadi Paran 9 find spots an area of $10 x 10 \mathrm{~m}$ was marked and all cores visible within this area were counted and typologically defined. The average distribution of cores at Nahal Paran 9 is low $\left(0.37\right.$ cores per $\left.\mathrm{m}^{2}\right)$. As this was only an initial exercise, none of the cores were collected. Of the 37 cores noted 26 were Levallois, and 11 were multifaceted non Levallois cores. The Levallois technology cores include Nubian cores, as well as centripetal, bidirectional and bidirectional point cores. All the cores recorded seem to belong to Middle Paleolithic industries, as they exhibit a planimetric exploitation of the cores' surfaces.

\section{Discussion}

Within the initial survey conducted, several Middle Paleolithic scatters with Nubian and Levallois centripetal cores were recognized. Two such localities are Nahal Zihor 6 and Nahal Paran 9. The core scatters from these two find spots typologically resemble the Negev Highland assemblages (Goder-Goldberger et al. 2016), as well as the core type combinations reported from the Al-Jawf region in Arabia (Hilbert et al. 2016: 2017). The cores collected and analysed from Nahal Paran 9 (Table 1) are typologically comparable to those found at $\mathrm{H} 2$ and Har Oded, two Middle Paleolithic surface sites located some $50 \mathrm{~km}$ North West of the Paran plains, in the central Negev (Figure 2). Nubian and Levallois centripetal core dimensions from Nahal Paran 9 are larger than the same core types from sites H2 (Goder- 
Goldberger et al. 2016: Table 4) and Har Oded (Boutié \& Rosen 1989: Tables 9 and 11), albeit they are wider.
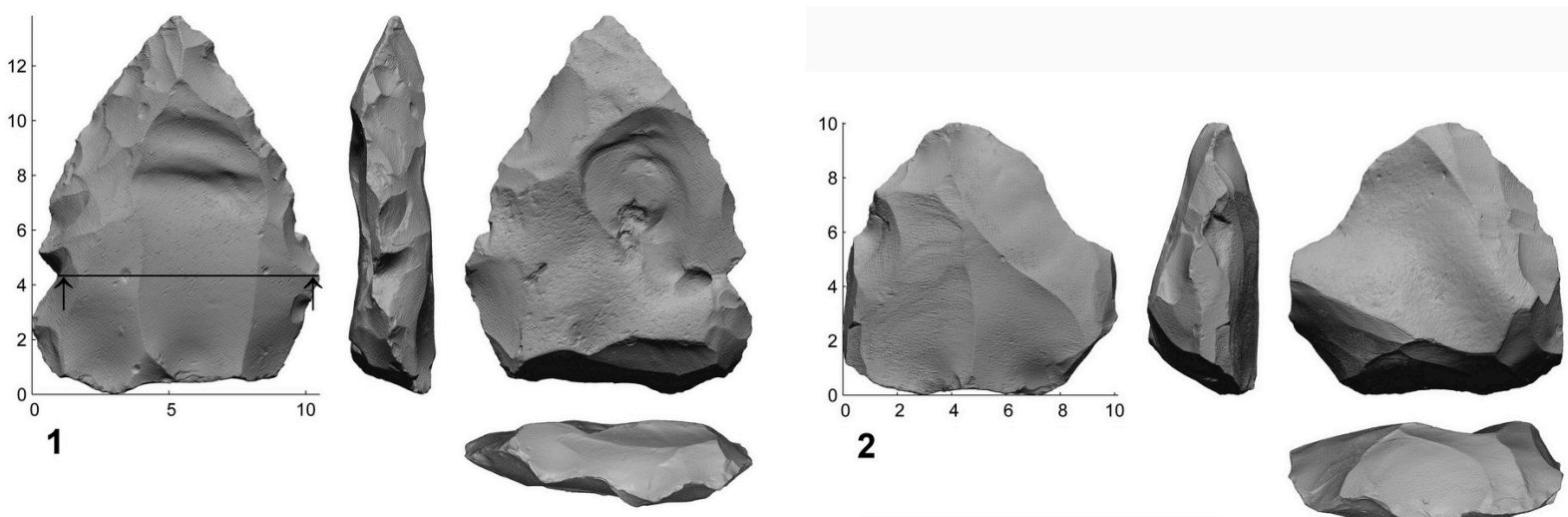

2

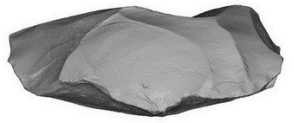

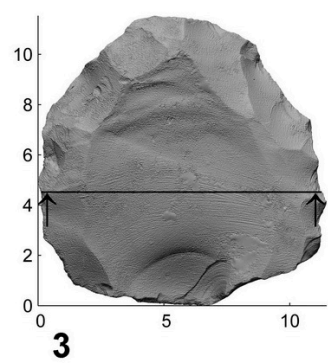
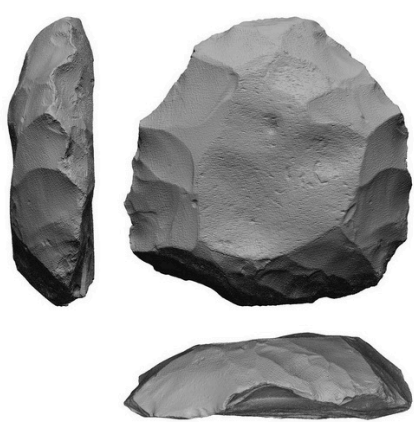

Figure 8. 3D scans of artifacts from Nahal Paran 9 - 1, Nubian core (346_3), 2, Levallois bidirectional preferential core (346_6), 3, Levallois centripetal preferential (346_2).

For Nahal Paran 9 only core distribution was recorded and when compared to other sites it is relatively low. The average core density at Nahal Paran 9 is 0.37 cores per $\mathrm{m}^{2}$, while at Har Oded, the average density is 2 cores per $\mathrm{m}^{2}$ (Boutié \& Rosen 1989). In the Al Jawf region, Arabia, artifact densities amounted to 1-4 artifacts per $\mathrm{m}^{2}$ (Hilbert et al. 2017), while the surveyed localities on the Abydos plateau, Egypt have an average density of 3.49 artifacts per $\mathrm{m}^{2}$, with the maximum density reported for a single locality of 144.83 artifacts per $\mathrm{m}^{2}$. Localities with the highest artifact densities appear on the ridges adjacent to the central wadi system (Olszewski et al. 2005).

Nahal Paran 9 and Nahal Zihor 6 localities are found in the relatively concise geographic area in which the Nubian technology incorporating the reduction of Nubian cores is found (Goder-Goldberger et al. 2016; Hilbert et al. 2017; Hussain et al. 2015; Rose et al. 2011;Van Peer \& Vermeersch 2007). Within this arid region movements of hunter-gatherer groups across the landscape were most likely facilitated by climatic wet phases. In central Arabia these wet phases are documented in fluvial-lacustrine archives (Breeze et al. 2016; Crassard et al. 2013; Groucutt et al. 2015; Rosenberg et al. 2011; 2012). Negev Humid periods (NHP) are recorded in speleothems (Vaks et al. 2006; 2007; 2010). Paleoenvironmental data indicate that widespread pluvial phases across Arabia occurred during MIS 5e (128-120 ka), MIS 5c (110-100 ka) and MIS 5a (90e74 ka) (Parker 2009; Petraglia et al. 2012; Rosenberg et al. 2011; 2012; Yehudai et al. 2017). The last humid period in the Negev (NHP-1) corresponds to both MIS5e and MIS5c (Vaks et al. 2007; 2010).

Convergence, dispersal, diffusion and diffusion with modifications can all be used to explain technological similarities between different regions (Goder-Goldberger et al. 2016; 
Hilbert et al. 2016; Groucutt et al. 2015; Will et al. 2015). Due to the restricted sample size and lack of chronological control over the surface scatters the two localities can, within the regional context, only cautiously be suggested to indicate events of dispersal or diffusion, or a combination of both, rather than convergence. Mechanisms of dispersal and diffusion operate across continuous geographical regions and time periods, and as a result are difficult to isolate in archaeological material culture. Examples for technological convergence may be suggested by the presence of Nubian-like cores in South Africa (Hallinan \& Shaw 2015; Will et al. 2015) and the Indian Thar desert (Blinkhorn et al. 2013). These two regions represent both geographical and chronological discontinuity with the region consisting of East Africa, the Nile Valley, the Negev desert and Arabia.

For a group of hunter-gatherers to disperse across geographical regions the landscape must be legible to them (Guiducci \& Burke 2016). Water ways have been shown to facilitate movement of populations (Breeze et al. 2016; Scerri et al. 2013). The ability to read the landscape and recognize landmarks allows them to find routes which can be retraced, and thus re-used over time. Wadi Paran and Wadi Zihor are two such landmarks which would enable easy traveling across the landscape to and from the Negev highlands and the Arava. Wadi Paran drains an area of more than $3800 \mathrm{~km}^{2}$ from eastern Sinai and the southern Negev towards the Dead Sea. This wadi could have acted as a path way allowing passage across the Arava to and from Arabia, the Negev highlands and the Mediterranean coast.

\section{Conclusions}

In this paper we presented finds from a cursory survey of several Middle Paleolithic find spots from the Arava, Israel. An attempt has been made to point out the relevance of these finds to those in a wider area including central Arabia and the Negev highlands. Similarities are revealed in the presence of Levallois Nubian cores alongside both Levallois centripetal and bidirectional cores. As the data presented here are based on a field survey, a complete technological analysis of the assemblages, while warranted, could not be performed. Further systematic surveying of the southern Negev and Arava together with a chronological attribution of these find spots is needed. This will assist in evaluating the cultural affinities of the groups that passed through this region and their preferred routes to cross the Negev desert into or from Arabia.

\section{Acknowledgments}

Photographs were taken by M.G-G and G.R. The 3D scans were done by Avshalom Karasik and the National Lab for digital documentation at the Israel Antiquities Authority. Figure 2 was prepared by Rachamim Shem-Tov from the Dead Sea and Arava Science Center. Part of the research was funded by the Israeli Ministry of Science, Technology and Space. We would specially like to thank Erella Hovers for taking part in the survey as well as her important contribution to the manuscript.

\section{References}

Amit, R., Enzel, Y. \& Sharon, D. 2006, Permanent Quaternary hyperaridity in the Negev, Israel, resulting from regional tectonics blocking Mediterranean frontal systems. Geology, 34(6): 509-512. doi:10.1130/G22354.1 
Avni, Y. 1998, פלאוגאוגרפיה וטקטוניקה בנגב המרכזי ובשולי בקע ים המלח בסוף הנאוגן והרבעון. (Report No. GSI/24/98), Israel Geological Survey, Jerusalem, 231 p. (In Hebrew with English abstract), ("Paleogeography and tectonics of the Central Negev and the Dead Sea Rift western margins during the late Neogene and Quaternary").

Avni, Y., Bartov, Y., Garfunkel, Z., \& Ginat, H. 2001, The Arava Formation - A Pliocene sequence in the Arava Valley and its western margin, southern Israel. Israel Journal of Earth Science, 50: 101-120.

Blome, M.W., Cohen, A.S., Tryon, C.A., Brooks, A.S., \& Russell, J. 2012, The environmental context for the origins of modern human diversity: a synthesis of regional variability in African climate 150,000-30,000 years ago. Journal of Human Evolution, 62: 563-592. doi:10.1016/j.jhevol.2012.01.011

Breeze, P.S., Groucutt H.S., Drake N.A., White T.S., Jennings R.P., \& Petraglia M.D. 2016, Palaeohydrological corridors for hominin dispersals in the Middle east 250-70,000 years ago. Quaternary Science Reviews, 144: 155-185. doi:10.1016/j.quascirev.2016.05.012

Boëda, E. 1988, Le Concept Levallois et évaluation de son champ d'application. L'Homme de Néandertal, 4: 13-26.

Boëda, E. 1995, Levallois: a volumetric construction method, a technique. In: The Definition and Interpretation of Levallois Technology (Dibble, H.L. \& Bar-Yosef, O., Eds.), Monographs in World Prehistory No. 23, Prehistory Press, Madison: p. 41-68.

Bordes, F., 1961. Typologie du Paléolithique Ancien et Moyen. Université de Bordeaux, Bordeaux: 85 p.

Boutié, P., \& Rosen, S. 1989, Des gisements moustériens dans le Néguev central: résultats préliminaires de prospections. In: Investigations in South Levantine Prehistory / Prehistoire de Sud-Levant (Bar-Yosef, O., \& Vandermeersch, B., Eds.), British Archaeological Reports Vol. 497, Oxford: p. 169-185.

Chiotti, L., Dibble, H.L., Olszewski, D.I., McPherron, S.P., \& Schurmans, U.A. 2009, Middle Paleolithic Lithic Technology from the Western High Desert of Egypt. Journal of Field Archaeology, 34: 307-318. doi:10.1179/009346909791070862

Crassard, R., \& Hilbert, Y.H. 2013, A Nubian Complex site from Central Arabia: Implications for Levallois Taxonomy and Human dispersals during the Upper Pleistocene. PLoS ONE, 8(7): e69221. doi:10.1371/journal.pone.0069221

Ginat, H. 1997, הפליאוגאגרפיה ושלבי התפתחות הנוף באגני הנחלים חיון וציחור : היבטים סדימנטולוגיים אקלימיים וטקטוניים, (Report No. GSI/19/97) Israel Geological Survey, Jerusalem: 206 p. (In Hebrew, English abstract), (" Paleogeography and the landscape evolution of the Nahal Hiyyon and Nahal Zihor basins (sedimentology, climatic and tectonic aspects)").

Ginat, H., Zilberman, E., \& Saragusti, I. 2003, Early Pleistocene fresh water lake deposits in Nahal Zihor, Southern Negev, Israel. Quaternary Research, 59: 445-458. doi:10.1016/S0033-5894(03)00029-2

Goder-Goldberger M., Gubenko N., \& Hovers E. 2016, “Diffusion with modifications”: Nubian assemblages in the central Negev highlands of Israel and their implications for Middle Paleolithic inter-regional interactions. Quaternary International, 408: 121-139. doi:10.1016/j.quaint.2016.02.008 
Goren-Inbar, N., \& Belfer-Cohen, A. 1998, Technological abilities of the Levantine Mousterians. In: Neandertals and Modern Humans in Western Asia, (Akazawa, T., Aoki, K., \& Bar-Yosef, O. Eds.), Plenum Press, New York and London: p. 205-221.

Groucutt, H.S., Petraglia, M.D., Bailey, G., Scerri, E.M., Parton, A., Clark-Balzan, L., Jennings, R.P., Lewis, L., Blinkhorn, J., Drake, N.A., \& Breeze, P.S. 2015, Rethinking the dispersal of Homo sapiens out of Africa. Evolutionary Anthropology: Issues, News, and Reviews, 24 (4): 149-164. doi:10.1002/evan.21455

Groucutt, H.S., White T.S., Clark-Balzan L., Parton A., Crassard R., Shipton C., Jennings R.P., Parker A.G., Breeze P.S., Scerri E.M.L., Asharekh A., \& Petraglia M.D. 2015, Human occupation of the Arabian Empty Quarter during MIS 5: evidence from Mundafan Al-Buhayrah, Saudi Arabia. Quaternary Science Reviews, 119: 116-135. doi:10.1016/j.quascirev.2015.04.020

Guichard, J., Guichard, G. 1965, The Early and Middle Palaeolithic of Nubia: a preliminary report. In: Contributions to the Prehistory of Nubia, (Wendorf, F., Ed.), Fort Burgwin Research Center and Southern Methodist University Press, Dallas: p. 57-116.

Guichard, J., Guichard, G. 1968, Contributions to the study of the Early and Middle Paleolithic of Nubia. In: The Prehistory of Nubia, Vol. I, (Wendorf, F., Ed.), Fort Burgwin Research Center and Southern Methodist University Press, Dallas: p. 148-193.

Guiducci, D., \& Burke A. 2016, Reading the landscape: legible environments and Hominin dispersals. Evolutionary Anthropology, 25: 133-141. doi:10.1002/evan.21484

Hallinan, E., \& Shaw, M. 2015, A new Middle Stone Age industry in the Tanwka Karoo, Northern Cape Province, South Africa. Antiquity Project Gallery, 89: 344. URL: http://antiquity.ac.uk/projgall/hallinan344

Hilbert, A.H., Crassard R., Rose, J.I., Geiling, J.M., \& Usik, V.I. 2016, Technological homogeneity within the Arabian Nubian Complex: Comparing chert and quartzite assemblages from central and southern Arabia. Journal of lithic Studies, 3(2). doi:10.2218/jls.v3i2.1420

Hilbert A.H., Crassard R., Charloux G., \& Loreto R., 2017, Nubian technology in northern Arabia: impact on interregional variability of Middle Paleolithic industries. Quaternary International, 435 (Part A): 77-93 doi:10.1016/j.quaint.2015.11.047

Kutzbach, J.E., \& Liu, Z. 1997, Response of the African monsoon to orbital forcing and ocean feedbacks in the middle Holocene. Science, 278: 440-443. doi:10.1126/science.278.5337.440

Larrasoaña, J.C., Roberts, A.P., \& Rohling, E.J. 2013, Dynamics of Green Sahara Periods and their role in hominin evolution. PLoS One, 8 (10): e76514 doi:10.1371/journal.pone.0076514

Marks, A.E., 1968. The Mousterian industries of Nubia. In: The Prehistory of Nubia, Vol. I, (Wendorf, F., Ed.), Fort Burgwin Research Center and Southern Methodist University Press, Dallas: p.194-314.

Mercier, N., Valladas, H., Froget, L., Joron, J.-L., Vermeersch, P.M., Van Peer, P., \& Moeyersons, J. 1999, Thermoluminescence dating of a Middle Palaeolithic occupation at Sodmein Cave, Red Sea Mountains (Egypt). Journal of Archaeological Science, 26: 1339-1345. doi:10.1006/jasc.1998.0369 
Olszewski D.I., Dibble H.L., Schurmans U.A., McPherron S.P., \& Smith J.R. 2005, High Desert Paleolithic survey at Abydos, Egypt. Journal of Field Archaeology, 30: 283-303. doi:10.1179/009346905791072233

Osborne, A.H., Vance, D., Rohling, E.J., Barton, N., Rogerson, M., \& Fello, N. 2008, A humid corridor across the Sahara for the migration of early modern humans out of Africa 120,000 years ago. PNAS, 105(43): 16444-16447. doi:10.1073/pnas.0804472105

Osmond, J.K., \& Dabous, A.A. 2004, Timing and intensity of groundwater movement during Egyptian Sahara pluvial periods by U-series analysis of secondary $\mathrm{U}$ in ores and carbonates. Quaternary Research, 61: 85-94. doi:10.1016/j.yqres.2003.09.004

Parker, A.G. 2009, Pleistocene climate change in Arabia: developing a framework for Hominin dispersal over the last $350 \mathrm{ka}$. In: The Evolution of Human Populations in Arabia: Paleoenvironments, Prehistory and Genetics,(Petraglia, M.D., \& Rose, J.I. Eds.), Springer Academic Publishers, Dordrecht: p. 151-168.

Petit-Maire, N., Carbonel, P., Reyss, J.L., Sanlaville, P., Abed, A., Bourrouilh, R., Fontugne, \& M., Yasin, S. 2010, A Vast Eemian Palaeolake in Southern Jordan $\left(29^{\circ} \mathrm{N}\right)$. Global and Planetary Change, 72: 368-373. doi:10.1016/j.gloplacha.2010.01.012

Petraglia, M.D., Alsharekh, A., Breeze, P., Clarkson, C., Crassard, R., Drake, N.A., Groucutt, H.S., Jennings, R., Parker, A.G., Parton, A., Roberts, R.G., Shipton, C., Metheson, C., Al-Omari, A., \& Veall, M.-A. 2012, Hominin dispersal into the Nefud desert and Middle Palaeolithic settlement along the Jubbah palaeolake, northern Arabia. PLoS One, 7 (11): e49840. doi:10.1371/journal.pone.0049840

Rose, J.I., Usik, V.I., Marks, A.E., Hilbert, Y.H., Galletti, C.S., Parton, A., Geiling, J-M., Černý, V., Morely, M.W., \& Roberts, R.G. 2011, The Nubian Complex of Dhofar, Oman: An African Middle Stone Age Industry in Southern Arabia. PLoS One, 6(11): e28239. doi:10.1371/journal.pone.0028239

Rosenberg, T.M., Preusser, F., Fleitmann, D., Schwalb, A., Penkman, K., Schmid, T.W., AlShanti, M.A., Kadi, K., \& Matter, A. 2011, Humid periods in southern Arabia: Windows of opportunity for modern human dispersal. Geology, 39(12): 1115-1119. doi:10.1130/G32281.1

Rosenberg, T.M., Preusser, F., Blechschmidt, I., Fleitmann, D., Jagher, R., \& Matter, A. 2012, Late Pleistocene palaeolake in the interior of Oman: a potential key area for the dispersal of anatomically modern humans out-of-Africa? Journal of Quaternary Science, 27(1): 13-16. doi:10.1002/jqs.1560

Rots, V., \& Van Peer, P. 2006, Early evidence of complexity in lithic economy: core-axe production, hafting and use at Late Middle Pleistocene site 8-B-11, Sai Island (Sudan). Journal of Archaeological Science, 33: 360-371. doi:10.1016/j.jas.2005.08.002

Scerri, E.M.L., Drake, N.A., Jennings, R., \& Groucutt, H.S. 2014, Earliest evidence for the structure of Homo sapiens populations in Africa. Quaternary Science Reviews, 101: 207-216. doi:10.1016/j.quascirev.2014.07.019

Schild, R. 1999, Geomorphology, stratigraphy and lithology of Prehistoric sites. In: An Archaeological Investigation of the Central Sinai, Egypt, Appendix D, (Eddy, F.W., \& Wendorf, F., Eds.). The American Research Center in Egypt, Inc. and University Press of Colorado, Cairo: p.311-312. 
Schmidt, C., Kindermann, K., Van Peer, P., \& Bubenzer, O. 2015, Multi-emission luminescence dating of heated chert from the Middle Stone Age sequence at Sodmein Cave (Red Sea Mountains, Egypt). Journal of Archaeological Science, 63: 94-103. doi:10.1016/j.jas.2015.08.016

Shea, J.J. 2003, The Middle Paleolithic of the East Mediterranean Levant. Journal of World Prehistory, 17 (4): 313-394. doi:10.1023/B:JOWO.0000020194.01496.fe

Shea, J.J. 2006, The Middle Paleolithic of the Levant: recursion and convergence. In: Transitions before the Transition, (Hovers, E., Kuhn, S.L. Eds.), Springer, New York: p. 189-212.

Torfstein, A., Goldstein, S.L., Kushnir, Y., Enzel, Y., Haug, G., \& Stein, M. 2015, Dead Sea drawdown and monsoonal impacts in the Levant during the last interglacial. Earth and Planetary Science Letters, 412: 235-244. doi:10.1016/j.epsl.2014.12.013

Usik, V.I., Rose, J.I., Hilbert, Y.H., Van Peer, P., \& Marks, A.E. 2013, Nubian Complex reduction strategies in Dhofar, southern Oman. Quaternary International, 300: 244-266. doi:10.1016/j.quaint.2012.08.2111

Vaks, A., Bar-Matthews, M., Ayalon, A., Matthews, A., Frumkin, A., Dayan, U., Halicz, L., Almogi-Labin, A., \& Schilman, B. 2006, Paleoclimate and location of the border between Mediterranean climate region and the Saharo-Arabian Desert as revealed by speleothems from the northern Negev Desert, Israel. Earth and Planetary Science Letters, 249: 384-399. doi:10.1016/j.epsl.2006.07.009

Vaks, A., Bar-Matthews, M., Ayalon, A., Halicz, L., \& Frumkin, A. 2007, Desert speleothems reveal climatic window for African exodus of Anatomically Modern Humans. Geology, 35: 831-834. doi:10.1130/G23794A.1

Vaks, A., Bar-Matthews, M., Matthews, A., Ayalon, A., \& Frumkin, A. 2010, Middle-Late Quaternary paleoclimate of northern margins of the Saharan-Arabian Desert: reconstruction from speleothems of Negev Desert, Israel. Quaternary Science Review, 29(19): 2647-62. doi:10.1016/j.quascirev.2010.06.014

Van Peer, P. 1992, The Levallois reduction strategy. Monographs in World Prehistory 13, Madison: 137 p.

Van Peer, P., Vermeersch, P.M., \& Paulissen, E. 2010, Chert Quarrying, Lithic Technology and a Modern Human Burial at the Palaeolithic Site of Taramsa 1, Upper Egypt. Leuven University Press, Leuven: 312 p.

Van Peer, P., \& Vermeersch, P.M. 2007, The place of northeast Africa in the early history of modern humans: new data and interpretations on the Middle Stone Age. In: Rethinking the Human Revolution, (Mellars, P., Boyle, K., Bar-Yosef, O., \& Stringer, C., Eds.), McDonald Institute for Archaeological Research, Cambridge: pp. 187-198.

Villa, P., Delagnes, A., Wadley, L., 2005. A late Middle Stone Age artifact assemblage from Sibutu (KwaZulu-Natal): comparisons with the European Middle Paleolithic. Journal of Archaeological Science, 32: 399-422. doi:10.1016/j.jas.2004.11.007

Waldmann, N., Torfstein, A. \& Stein, M. 2010, Northward intrusions of low-and mid-latitude storms across the Saharo-Arabian belt during past Interglacials. Geology, 38(6): 567570. doi:10.1130/G30654.1 
Will, M., Mackay, A., \& Philips, N. 2015, Implications of Nubian-like core reduction systems in southern Africa for the identification of early modern human dispersals. PLoS One, 10(6): e0131824. doi:10.1371/journal.pone.0131824

Yehudai, M., Lazar, B., Bar, N., Kiro, Y., Agnon, A., Shaked, Y., \& Stein, M. 2017, U-Th dating of calcite corals from the Gulf of Aqaba, Geochimica et Cosmochimica Acta, 198: 285-298. doi:10.1016/j.gca.2016.11.005 